21. Knudsen A., Benfield T., Kofoed K. Cytokine expression during syphilis infection in HIV-1-infected individuals. Sex. Transm. Dis. 2009. Vol. 36, No. 5. P. 300-304. DOI: https://doi.org/10.1097/OLQ.0b013e318193ca26
22. Lusiak M., Podwińska J. Interleukin 10 and its role in the regulation of the cell-mediated immune response in syphilis. Arch. Immunol Ther. Exp. 2001. Vol. 49, No. 6. P. 417-421.

Стаття надійшла до редакції 24.06.2019

\author{
O.M. Raznatovska ${ }^{1}$, \\ A.V. Fedorec ${ }^{2}$, \\ M.O. Shalmina ${ }^{1}$, \\ T.A. Grekova ${ }^{1}$
}

\section{CLINICAL FEATURES OF PREGNANCY IN MULTIDRUG-RESISTANT TUBERCULOSIS AND TYPE 1 DIABETES MELLITUS COMORBIDITIES (a case report)}

\author{
Zaporizhzhia State Medical University ${ }^{1}$ \\ Maiakovskyi av., 26, Zaporizhzhia, 69035, Ukraine \\ MI «Zaporizhzhia Regional TB Clinical Dispensary» ${ }^{2}$ \\ Perspektyvna, 2, Zaporizhzhia, 69106, Ukraine \\ Запорізький державний медичний університет ${ }^{I}$ \\ пр. Маяковського, 26, Запоріжжя, 69035, Украӥна \\ КУ "Запорізький обласний протитуберкульозний клінічний диспансер" ЗОР 2 \\ вул. Перспективна, 2, Запоріжжя, 69106, Україна \\ e-mail:zsmu@zsmu.zp.ua
}

Цитування: Медичні перспективи. 2019. Т. 24, № 3. С. 101-105

Cited: Medicni perspektivi. 2019;24(3):101-105

Key words: pregnancy, multidrug-resistant tuberculosis, type 1 diabetes mellitus

Ключові слова: вагітність, мультирезистентний туберкульоз, иукровий діабет 1-го типу

Ключевые слова: беременность, мультирезистентный туберкулез, сахарный диабет 1-го типа 
to antimycobacterial agents and negative dynamics by follow-up chest X-ray were diagnosed. The feature of pregnancy course in MRD-TB and TIDM comorbidities was an unfavorable coexistence of both these diseases simultaneously resulting in an induced abortion. In this case, doctors to working with patients suffering from both MRD-TB and TIDM are recommended to advise patients the use of contraception in order to prevent pregnancy during treatment of active MRD-TB.

Реферат. Особливості перебігу вагітності при одночасному захворюванні на мультирезистентний туберкульоз і цукровий діабет 1-го типу (клінічний випадок). Разнатовська О.М., Федорець А.В., Шальміна М.О., Грекова ТА. Мета дослідження - доповнення літературних джерел даними про особливості перебігу вагітності при одночасному захворюванні на мультирезистентний туберкульоз (МРТБ) $і$ иукровий діабет (ЦД) 1-го типу на прикладі власного спостереження. Описано клінічний випадок власного спостереження перебігу вагітності при одночасному захворюванні на МРТБ і ЦД 1-го типу. У представленому клінічному випадку пацієнтка 38 років, хвора на ЦД 1-го типу, захворіла на вперие діагностований МРТБ. На тлі адекватного лікування МРТБ та ЦД 1-го типу в паџієнтки загальний стан постійно коливався від задовільного до середньотяжкого з проявами інтоксикаційного синдрому та появою нефропатії, діагностовано ендометріоз тіла матки з періодичними кров'янистими виділеннями, визначалися відсутність клінічно-рентгенологічної динаміки та конверсї мокротиння. Через 3 місяці інтенсивної фази антимікобактеріальної терапї пацієнтка завагітніла. Враховуючи медичні показання (МРТБ, відсутність конверсіі мокротиння і клінічно-рентгенологічної динаміки, ЦД 1-го типу середньої тяжкості, нефропатія) та ендометріоз тіла матки з кров'янистими виділеннями, пацієнтці було запропоновано зробити штучне переривання вагітності, на щзо вона погодилася. На тлі негативної динаміки в пацієнтки на 7-му місяці антимікобактеріальної терапї була діагностована розширена резистентність мікобактерій туберкульозу до антимікобактеріальних препаратів. Особливостями перебігу вагітності при одночасному захворюванні на МРТБ і ЦД 1-го типу був несприятливий фон, спричинений циими двома захворюваннями. Наслідком изього стало штучне переривання вагітності. Рекомендаціями в цъьому випадку є робота лікарів з пацієнтками, хворими одночасно на МРТБ і ЦД 1-го типу, у напрямку використання контращепщиї з метою запобігання вагітності на період лікування активного МРТБ.

To date, pulmonary multidrug-resistant tuberculosis (MRD-TB) remains one of the top causes of death among chronic communicable diseases [8] and diabetes mellitus (DM) - among chronic noncommunicable diseases [7].

Type $1 \mathrm{DM}$ is characterized by a deficiency in insulin production, and people with this type of DM require lifelong administration of exogenous insulin [7] and optimal glycemic control [9]. It has been found that in the vast majority of pregnant women, $\mathrm{DM}$ is associated with an increased risk of both diabetic and obstetric complications [2] and this risk is doubled in the case of T1DM [3]. Poorly controlled DM in pregnant women is related to dramatically adverse effect on both maternal and fetal health outcomes increasing the risk of fetal loss, stillbirth, perinatal and maternal mortality as well as developing birth defects which are the most common cause of perinatal mortality [7].

In T1DM pregnant women, the frequency of preterm labor is $60 \%$ [7]. There is strong evidence that T1DM pregnant women are at high risk for hypoglycemia occurring early in gestation which can cause intrauterine growth retardation [4]. At the same time, MRD-TB pregnant women also demonstrate a higher incidence of adverse treatment and childbirth outcomes as compared to pregnant women with sensitive causative agents of tuberculosis [1] together with serious maternal and fetal health risks [10].
All this is conducive to the growth of the number of patients with a combined course of these two diseases which mutually and adversely affect each other. It has long been known that tuberculosis complications, a prolonged time of sputum culture conversion, high rate of treatment failure are DMassociated [12]. Relatedly, tuberculosis activates a range of pathways associated with diabetic complications. A specific process leads to DM decompensation due to worse glycemic control, causing glucose intolerance [6]. Gadallah M. A. et al. [11] indicate that the predictors of MRD-TB unsuccessful treatment are the delay in sputum culture conversion, moderate or extensive lung affection and DM.

Combined course of MRD-TB and T1DM becomes especially unfavorable for pregnant women.

Objective - to update the literature data with the clinical features of pregnancy in MRD-TB and T1DM comorbidities based on an example from own clinical experience.

MATERIALS AND METHODS OF RESEARCH

We report the clinical case of pregnancy course in MRD-TB and T1DM comorbidities based on our own clinical experience. A patient received inpatient treatment in the Department of Pulmonary Tuberculosis No 3 of the Clinical base of Phthisiology and Pulmonology Department of ZSMU at the Municipal Institution "Zaporizhzhia Regional Tuberculosis Clinical Dispensary" (ZRTBCD). 


\section{Clinical case presentation and discussion}

A 38-year-old woman G. was admitted to the ZRTBCD with newly diagnosed tuberculosis (NDTB), right lung infiltration. Destruction $(+)$, Mycobacterium tuberculosis (MBT) + , microscopy (M) +, Category 1. T1DM, moderate severity. Antimycobacterial therapy (AMBT) by category 1 was prescribed according to the Unified Clinical Protocol (UCP) "Tuberculosis" [5].

After being further examined with the help of molecular-genetic (MG) test, the patient presented MTB (+), MG (+), rifampicin (Rif) + . Based on the data obtained, the diagnosis was established: rifampicin resistant tuberculosis (RifTB), right lung infiltration. Destruction $(+), \mathrm{MBT}(+), \mathrm{M}(+), \mathrm{MG}(+)$, Rif $(+)$, Category 4 (NDTB). T1DM, moderate severity.

AMBT by category 4 was prescribed taking into account the drug sensitivity test (DST) data according to the UCP "Tuberculosis" [5] and insulin therapy following the endocrinologist recommendations.

After 2 weeks of inpatient treatment, she presented rise in body temperature up to $38^{\circ} \mathrm{C}$ complaining of menstrual disorder and bloody vaginal discharge. Clinical blood analysis (CBA) was as follows: hemoglobin $(\mathrm{Hb})-115 \mathrm{~g} / \mathrm{l}$; erythrocytes $(\mathrm{Er})-4.92 \times 10^{12} / 1$, leukocytes (L) - $12.0 \times 10^{9} / 1$, erythrocyte sedimentation rate (ESR) - $36 \mathrm{~mm} / \mathrm{h}$, banded (b) $-12 \%$, segmented (s) $-75 \%$, eosinophils (e) $-2 \%$, lymphocytes (l) $-7 \%$, monocytes $(\mathrm{m})-4 \%$.

The patient was consulted by a gynecologist. Her past gynecological history was unremarkable and she was not under medical check-up. Two pregnancy tests were negative. Transvaginal ultrasound was performed demonstrating echo signs of adenomyosis, heterogenous structure and thickness of the endometrium (hypoplasia?), small amount of free fluid in the pelvic cavity (Fig.).

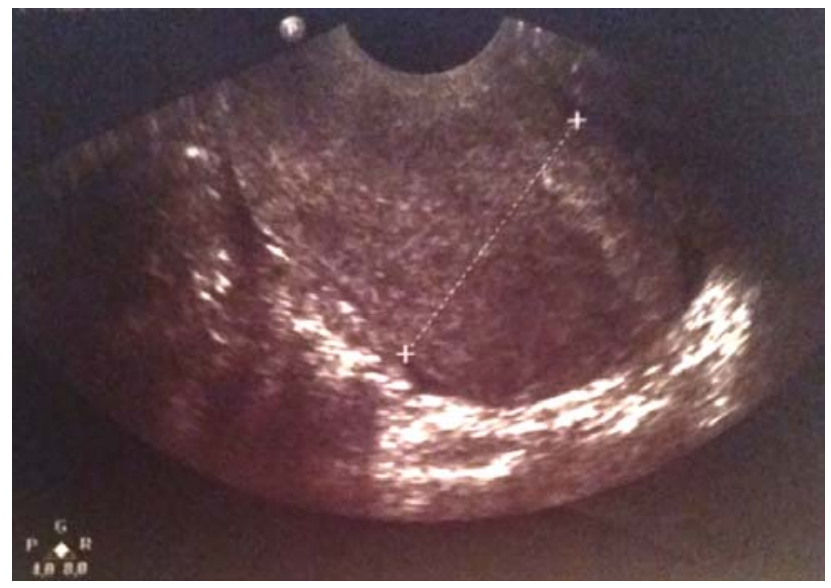

Transvaginal ultrasound
Based on these findings, the gynecologist established the diagnosis: menstrual disorder, adenomyosis. An appropriate treatment was prescribed.

After a month of inpatient treatment, the results of sputum culture in a liquid medium were obtained suggesting MBT resistance to first-line antimycobacterial drugs (AMBD) - isoniazid (H), rifampicin $(\mathrm{R})$ and pyrazinamide $(\mathrm{Z})$. The patient was presented to MRD-TB expert panel and as a result the diagnosis was made: MRD-TB, right lung infiltration. Destruction $(+)$, MBT $(+), \mathrm{M}(+), \mathrm{MG}(+)$, Rif (+), Resistance I (HRZ), Category 4 (NDTB). T1DM, moderate severity. The appropriate therapy was administered again taking into account the results of DST according to the UCP "Tuberculosis" [5].

The patient was under regular follow-up of the endocrinologist.

In the treatment course, her general condition was unstable from satisfactory to moderately severe with intoxication syndrome manifestations. The follow-up chest X-ray revealed no changes. There was no sputum culture conversion. From the third month of inpatient treatment, the patient demonstrated an increase in serum creatinine level up to $110.0 \mu \mathrm{mol} / \mathrm{L}$ (upper reference limit: $97 \mu \mathrm{mol} / \mathrm{L}$ ) and urea level up to $9.1 \mathrm{mmol} / \mathrm{L}$ (upper reference limit: $7.2 \mathrm{mmol} / \mathrm{L}$ ).

In this context, after the intensive phase of AMBT within 4 months, the patient complained of: menstrual disorder, bloody vaginal discharge and intoxication syndrome manifestations again. The follow-up consultation of gynecologist. The pregnancy test appeared to be positive. Transabdominal pelvic US showed echo signs of pregnancy, 45 weeks of gestation.

Based on the medical indications, the patient was requested to terminate pregnancy, and she consented. The postoperative period was uneventful.

The DST data obtained after the intensive phase of AMBT within 7 months were indicative of the extensive drug-resistance of MBT to AMBD: resistance I (HRZ), resistance to second-line AMBD ofloxacin (Ofx), kanamycin (Km) and capreomycin $(\mathrm{Cm})$. The patient was prescribed the appropriate treatment regimen based on DST data according to the UCP "Tuberculosis" [5].

There was no sputum culture conversion throughout the entire intensive phase of AMBT (8 months). Radiological dynamics was weak positive with conglomerate mass lesions. The patient was repeatedly presented to surgical expert panel for elective surgery, but she categorically refused.

\section{RESULTS AND DISCUSSION}

Currently, there is consensus that neither active MRD-TB nor DM requires termination of pregnancy. 
Safe treatment in usual management regimens during pregnancy seems possible but needs appropriate individual decision-making to eliminate the possible risks of adverse effects due to teratogenicity $[7,8]$.

In the presented clinical case, the 38-year-old woman suffering from T1DM diabetes developed newly diagnosed MRD-TB. Despite the adequate treatment of MRD-TB and T1DM, her general condition was unstable from satisfactory to moderately severe with manifestations of intoxication syndrome and nephropathy. Adenomyosis with periodic bloody vaginal discharge was diagnosed. There was no clinical-radiological dynamics and sputum culture conversion. After the intensive phase of antimycobacterial therapy within 3 months, the patient got pregnant.

In Ukraine, severe clinical forms of tuberculosis (progressive, chemoresistant or severely complicated) and severe DM are among medical indications for pregnancy termination. Therefore, taking into account medical indications (MRD-TB, absence of sputum culture conversion and clinical-radio- logical dynamics, moderate severity of T1DM, nephropathy) and adenomyosis with bloody vaginal discharge, the patient was requested to terminate pregnancy, and she consented.

On month 7 of antimycobacterial therapy, an extensive drug-resistance of MBT to AMBD and negative dynamics by follow-up chest X-ray were diagnosed.

\section{CONCLUSIONS}

1. The feature of pregnancy course in MRD-TB and T1DM comorbidities was an unfavorable coexistence of both these diseases simultaneously resulting in an induced abortion.

2. In this case, doctors to working with patients suffering from both MRD-TB and T1DM are recommended to advise patients the use of contraception in order to prevent pregnancy during treatment of active MRD-TB.

Conflicts of interest. The authors declare no conflict of interest.

\section{REFERENCES}

1. Jakovlev AA, Mordyk AV, Zhukova NV, Antropova VV, Leont'ev VV, Nikolaeva II. [Analysis of the course and outcome of tuberculosis and pregnancy when they are combined in patients of reproductive age]. Sibirskoe medicinskoe obozrenie [Internet]. 2012;1(73). Russian. Available from: https://cyberleninka.ru/article/n/analiztecheniya-i-ishodov-tuberkuleza-i-beremennosti-pri-ihsochetanii-u-patsientok-reproduktivnogo-vozrasta.

2. Rahimdzhanova MT, Ismailov SI, Tashmanova AB, Ahmedova MS. [The study of the course of pregnancy and its outcomes with the analysis of possible risk factors in patients with type 1 diabetes]. Mezhdunarodnyi endokrinologicheskii zhurnal. 2014;2(58):28-30. Russian.

3. Nikonova LV, Tishkovskaja SV, Gadomskaja VI, Davydchik JV, Gulinskaja OV. [Diabetes and pregnancy. Part II. Course, patient management tactics]. J of the Grodno State Medical University. 2017;15(4):368-74. Russian. doi: https://doi.org/10.25298/2221-8785-2017-15-4-368-374.

4. Torosian KJ, Nepso JR, Novikova VA, Penzhojan GA. [Diabetes mellitus type 1 and pregnancy: a clinical perspective]. Sovremennye problemy nauki i obrazovanija [Internet]. 2016;4. Russian. Available from: $\mathrm{http}: / /$ www.science-education.ru/ru/article/view?id=24998.

5. [Unified clinical protocols of primary, secondary (specialized) and tertiary (highly specialized) medical care for adults "Tuberculosis": Ministry of Health of Ukraine Order No. 620 of December 31, 2014]. Kyiv, MOZ Ukrainy. 2014;171. Ukrainian.
6. Riza AL, Pearson F, Ugarte-Gil C, Alisjahbana B, van de Vijver S, Panduru NM, et al. Clinical management of concurrent diabetes and tuberculosis and the implications for patient services. Lancet Diabetes Endocrinol. 2014;2(9):740-53.

doi: https://doi.org/10.1016/S2213-8587(14)70110-X

7. Global report on diabetes. Geneva: World Health Organization. 2016;86.

8. Global Tuberculosis Report 2018. Geneva: World Health Organization. 2019;174.

9. Murphy HR, Elleri D, Allen JM, Harris J, Simmons D, Rayman G, et al. Closed-loop insulin delivery during pregnancy complicated by type 1 diabetes. Diabetes Care. 2011;34:406-11. doi: https://doi.org/10.2337/dc10-1796

10. Rohilla M, Joshi B, Jain V, Kalra J, Prasad GRV. Multidrug-Resistant Tuberculosis during Pregnancy: Two Case Reports and Review of the Literature. Case Rep Obstet Gynecol. 2016:4.

doi: https://doi.org/10.1155/2016/1536281

11. Gadallah MA, Mokhtar A, Rady M, El-Moghazy E, Fawzy M, Kandil SK. Prognostic factors of treatment among patients with multidrug-resistant tuberculosis in Egypt. J Formos Med Assoc. 2016;115(11):997-1003. doi: https://doi.org/10.1016/j.jfma.2015.10.002

12. Siddiqui A. Role of Diabetes in prevalence of Tuberculosis. J Diabetes Metab. 2011;2(9):170. doi: https://doi.org/10.4172/2155-6156.1000170 


\section{СПИСОК ЛІТЕРАТУРИ}

1. Анализ течения и исходов туберкулеза и беременности при их сочетании у пациенток репродуктивного возраста / А. А. Яковлев та ін. Сибирское медицинское обозрение. 2012. Т. 73, № 1 . URL: https://cyberleninka.ru/article/n/analiz-techeniya-iishodov-tuberkuleza-i-beremennosti-pri-ih-sochetanii-upatsientok-reproduktivnogo-vozrasta

2. Рахимджанова М. Т., Исмаилов С. И., Ташманова А. Б., Ахмедова М. С. Изучение течения беременности и ее исходов с анализом возможных факторов риска у больных сахарным диабетом 1-го типа. Междунар. эндокринологический журнал. 2014. Т. 58, № 2. C. 28-30.

3. Сахарный диабет и беременность. Часть II. Течение, тактика ведения пациентов / Л. В. Никонова та ін. J. Grodno State Medical University. 2017. Vol. 15, No. 4. C. 368-374. DOI: https://doi.org/10.25298/22218785-2017-15-4-368-374

4. Торосян К. Э., Н Непсо Ю. Р., Новикова В. А., Пенжоян Г. А. Сахарный диабет 1 типа и беременность: клинические перспективы. Совр. проблемь науки $и$ образования. 2016. № 4. URL: http://www.scienceeducation.ru/ru/article/view?id=24998

5. Уніфікований клінічний протокол первинної, вторинної (спеціалізованої) та третинної (високоспеціалізованої) медичної допомоги дорослим.
Туберкульоз: наказ МО3 України № 620 від 31.12.2014 р. Київ: МОЗ України, 2014. 171 с.

6. Clinical management of concurrent diabetes and tuberculosis and the implications for patient services / A. L. Riza et al. Lancet Diabetes Endocrinology. 2014. Vol. 9, No. 2. C. 740-753.

DOI: https://doi.org/10.1016/S2213-8587(14)70110-X

7. Global report on diabetes. Geneva: World Health Organization, $2016.86 \mathrm{p}$.

8. Global Tuberculosis Report 2018. Geneva: World Health Organization, 2019. 174 p.

9. Closed-loop insulin delivery during pregnancy complicated by type 1 diabetes / H. R. Murphy et al. Diabetes Care. 2011. Vol.34. P. 406-411. DOI: https://doi.org/10.2337/dc10-1796

10. Multidrug-Resistant Tuberculosis during Pregnancy: Two Case Reports and Review of the Literature / M. Rohilla et al. Case Rep. Obstet. Gynecol. 2016. 4 p. DOI: https://doi.org/10.1155/2016/1536281

11. Prognostic factors of treatment among patients with multidrug-resistant tuberculosis in Egypt / M. A. Gadallah et al. J. Formos Med Assoc. 2016. Vol. 115, No. 11. P. 9971003. DOI: https://doi.org/10.1016/j.jfma.2015.10.002

12. Siddiqui A. Role of Diabetes in prevalence of Tuberculosis. J. Diabetes Metab. 2011. Vol. 9, No. 2. P. 170. DOI: https://doi.org/10.4172/2155-6156.1000170

Стаття надійшла до редакції 17.07.2019 